\title{
Profil Penderita Morbus Hansen di Rawat Inap RSUP Prof. Dr. R. D. Kandou Manado Periode 2016-2018
}

\author{
Deivy A. Makalew, ${ }^{1}$ Grace M. Kapantow, ${ }^{2}$ Herry E. J. Pandaleke ${ }^{2}$
}

\author{
${ }^{1}$ Program Studi Pendidikan Dokter Fakultas Kedokteran Universitas Sam Ratulangi Manado \\ ${ }^{2}$ Bagian/SMF Ilmu Kesehatan Kulit dan Kelamin Fakultas Kedokteran Universitas Sam \\ Ratulangi Manado - RSUP Prof. Dr. R. D. Kandou Manado \\ Email: alfamakalew@gmail.com
}

\begin{abstract}
Morbus Hansen (MH) is a chronic infectious disease caused by Mycobacterium leprae. World Health Organization data showed that in 2018, Indonesia was the third rank in the world with incidences of 17,017 cases. This study was aimed to determine the profile of MH patients at Irina F-Dermatovenereology of Prof. Dr. R. D. Kandou Hospital. This was a descriptive retrospective study by evaluating medical record files of $\mathrm{MH}$ patients hospitalized at Irina F-Dermatovenereology, Prof. Dr. R. D. Kandou Hospital from 2016 to 2018. The results showed that the distribution of $\mathrm{MH}$ patients in 2016-2018 was 14 patients, 20 patients, and 18 patients respectively. Most patients were in the age group of 25-34 years (38.46\%). Males were more common than females (4.8:1). Most patients were from Manado. All patients had multibacillary (MB) type MH and ENL was the most common reaction (86.54\%). The comorbidities were gastrointestinal disorders, electrolyte imbalance, and anemia. In conclusion, the number of hospitalized MH patients was slightly increased from 2016 to 2017 and then was decreased insignificantly in 2018. Most patients were male, in the age group of 25-34 years, came from Manado, multibacillary type MH, had ENL reaction and comorbidity of gastrointestinal disorders.
\end{abstract}

Keywords: Morbus Hansen, hospitalized patients

\begin{abstract}
Abstrak: Morbus Hansen (MH) merupakan penyakit infeksi kronik yang disebabkan oleh Mycobacterium leprae. Data World Health Organization (WHO) pada tahun 2018 menunjukkan bahwa Indonesia menempati peringkat ketiga di dunia dengan jumlah kasus baru mencapai 17.017 kasus. Penelitian ini bertujuan untuk mengetahui profil penderita MH di Irina F Kulit dan Kelamin RSUP Prof. Dr. R. D. Kandou Manado. Jenis penelitian ialaht deskriptif retrospektif dengan cara mengevaluasi berkas rekam medis penderita $\mathrm{MH}$ yang dirawat inap di Irina F Kulit dan Kelamin RSUP Prof. Dr. R. D. Kandou Manado pada periode 2016-2018. Hasil penelitian mendapatkan distribusi penderita MH pada tahun 2016 sebanyak 14 pasien, tahun 2017 sebanyak 20 pasien, dan tahun 2018 yaitu 18 pasien. Kelompok usia terbanyak ialah 25-34 tahun $(38,46 \%)$. Penderita laki-laki lebih banyak dibandingkan perempuan $(4,8: 1)$. Penderita terbanyak berasal dari Kota Manado. Semua penderita memiliki MH tipe Multibasiler (MB). Reaksi ENL merupakan tipe reaksi yang terbanyak (86,54\%). Penyakit penyerta yang banyak didapati ialah gangguan gastrointestinal, gangguan elektrolit dan anemia. Simpulan penelitian ini ialah penderita $\mathrm{MH}$ yang dirawat inap mengalami peningkatan dari tahun 2016 sampai 2017, sedikit menurun pada tahun 2018 namun tidak bermakna. Penderita yang terbanyak ialah kelompok usia 25-34 tahun, jenis kelamin laki-laki, asal Kota Manado, MH tipe Multibasiler (MB), reaksi tipe ENL, penyakit penyerta gangguan gastrointestinal.
\end{abstract}

Kata kunci: Morbus Hansen, pasien rawat inap 


\section{PENDAHULUAN}

Morbus Hansen (MH) atau yang disebut juga dengan kusta adalah penyakit infeksi kronik yang disebabkan oleh $\mathrm{Myco}$ bacterium Leprae yang menyerang beberapa bagian tubuh terutama jalan napas bagian atas, kulit, dan saraf tepi. Masa inkubasi dari $M$. leprae sangat bervariasi, umumnya 3-5 tahun. ${ }^{1}$ Morbus Hansen merupakan penyebab kecacatan tertinggi terkait infeksi di banyak negara endemik $\mathrm{MH}^{2}$

Menurut data World Health Organization (WHO), jumlah kasus baru MH pada tahun 2018 di 159 negara yang ada di semua regional WHO ialah sebanyak 208.619 kasus. $^{3}$ Indonesia menempati peringkat ketiga di dunia dengan jumlah kasus sebanyak 17.017 kasus, setelah India dengan jumlah 120.334 kasus dan Brasil sebanyak 28.660 kasus. $^{4}$

Di Indonesia, menurut data dari $\mathrm{Ke}$ menterian Kesehatan Republik Indonesia pada tahun 2018, jumlah kasus baru MH ialah sebanyak 14.397 kasus yang terdiri dari 12.377 kasus $(85,97 \%) \mathrm{MH}$ tipe multibasiler dan 2.020 kasus $(14,03 \%) \mathrm{MH}$ tipe pausibasiler (PB). Dari 14.397 kasus, ditemukan bahwa penderita laki-laki sebanyak $9.016(62,62 \%)$ dan perempuan sebanyak $5.381(37,38 \%){ }^{5}$

Di Provinsi Sulawesi Utara, menurut data dari Kementerian Kesehatan Republik Indonesia pada tahun 2016 jumlah kasus baru $\mathrm{MH}$ ialah sebanyak 379 kasus dengan angka prevalensi sebesar 1,65 per 10.000 penduduk dari jumlah penduduk yang berjumlah 2.436.921 jiwa; pada tahun 2017 sebanyak 454 kasus dengan angka prevalensi sebesar 2,04 per 10.000 penduduk dari jumlah penduduk yang berjumlah 2.461.028 jiwa; dan pada tahun 2018 sebanyak 443 kasus dengan angka prevalensi sebesar 2,79 per 10.000 penduduk dari jumlah penduduk yang berjumlah 2.484.392 jiwa. Dari data ini dapat dilihat bahwa angka prevalensi kasus $\mathrm{MH}$ di Sulawesi Utara mengalami peningkatan. ${ }^{5-7}$

Berdasarkan data ini dapat dilihat bahwa MH masih menjadi masalah kesehatan secara global dengan jumlah temuan kasus baru yang masih tinggi setiap tahunnya Oleh karena itu peneliti merasa tertarik untuk mengetahui profil penderita $\mathrm{MH}$, khususnya yang dirawat inap di Irina F Kulit dan Kelamin RSUP Prof. Dr. R. D. Kandou Manado periode 2016-2018.

\section{METODE PENELITIAN}

Penelitian ini dilakukan di Bagian Ilmu Kesehatan Kulit dan Kelamin RSUP Prof. Dr. R. D. Kandou Manado. Jenis penelitian ini ialah deskriptif retrospektif. Data penelitian menggunakan rekam medik penderita dengan diagnosis $\mathrm{MH}$ yang di rawat inap di Irina F Kulit dan Kelamin RSUP Prof. Dr. R. D. Kandou Manado.

Populasi penelitian yaitu seluruh data penderita yang dirawat inap di Irina F Kulit dan Kelamin RSUP Prof. Dr. R. D. Kandou Manado periode 2016-2018. Sampel penelitian yaitu data penderita dengan diagnosis $\mathrm{MH}$ yang dirawat inap di Irina F Kulit dan Kelamin RSUP Prof. Dr. R. D. Kandou Manado periode 2016-2018 dengan data berkas rekam medik yang lengkap dan bisa dievaluasi. Variabel penelitian yang digunakan meliputi usia, jenis kelamin, tempat tinggal (kabupaten/kota), tipe $\mathrm{MH}$, tipe reaksi $\mathrm{MH}$, dan penyakit penyerta.

Penelitian ini telah mendapat persetujuan dari Komisi Etik Penelitian Kesehatan RSUP Prof. Dr. R. D. Kandou Manado, dengan nomor keterangan layak etik yaitu No. 040/EC/KEPK-KANDOU/X/2019.

\section{HASIL PENELITIAN}

Tabel 1 memperlihatkan bahwa terdapat 52 penderita yang didiagnosis dengan MH dari total 149 penderita yang dirawat inap di Irina F Kulit dan Kelamin.

Tabel 1. Distribusi penderita $\mathrm{MH}$ di Irina $\mathrm{F}$ Kulit dan Kelamin RSUP Prof. Dr. R. D. Kandou Manado

\begin{tabular}{cccc}
\hline Tahun & $\begin{array}{c}\text { Jumlah } \\
\text { populasi }\end{array}$ & $\begin{array}{c}\text { Jumlah } \\
\text { penderita }\end{array}$ & $(\boldsymbol{\%})$ \\
\hline 2016 & 40 & 14 & 35,00 \\
2017 & 61 & 20 & 32,79 \\
2018 & 48 & 18 & 37,50 \\
Jumlah & 149 & 52 & 34,90 \\
\hline
\end{tabular}


Tabel 2 memperlihatkan distribusi berdasarkan usia penderita. Kelompok usia terbanyak terdapat pada kelompok usia 2534 tahun yaitu sebanyak 20 penderita $(38,46 \%)$, paling sedikit terdapat pada kelompok usia 5-14 tahun yaitu 1 penderita $(1,92 \%)$, dan pada kelompok usia 0-4 tahun tidak ditemukan penderita.

Tabel 3 memperlihatkan distribusi berdasarkan jenis kelamin. Laki-laki sebanyak 43 penderita $(82,69 \%)$ dan perempuan sebanyak 9 penderita $(17,31 \%)$ dengan perbandingan 4,8:1.

Tabel 4 memperlihatkan distribusi berdasarkan tempat tinggal penderita $\mathrm{MH}$. Didapatkan bahwa kabupaten/kota dengan jumlah pasien terbanyak ialah Kota Manado dengan jumlah 19 penderita $(36,54 \%)$ sedangkan kabupaten/kota dengan jumlah penderita paling sedikit ialah Kota Bitung, Kab. Minahasa Tenggara, Kab. Minahasa Selatan, Kab. Bolaang Mongondow Timur, Kab. Sitaro, dan luar Sulawei Utara dengan jumlah 1 penderita $(1,92 \%)$. Tidak didapatkan penderita $\mathrm{MH}$ yang berasal dari Kota Kotamobagu, Kab. Bolaang Mongondow
Selatan, Kab. Bolaang Mongondow Utara, Kab. Sangihe, dan Kab. Talaud.

Tabel 5 memperlihatkan distribusi berdasarkan tipe MH. Didapatkan bahwa semua penderita $\mathrm{MH}$ yaitu sebanyak 52 penderita (100 \%) memiliki MH tipe Multibasiler (MB).

Tabel 6 memperlihatkan distribusi berdasarkan tipe reaksi $\mathrm{MH}$ yang dialami oleh penderita. Didapatkan bahwa reaksi ENL merupakan tipe reaksi yang paling banyak dialami oleh penderita MH yaitu sebanyak 45 penderita $(86,54 \%)$, dan terdapat 1 penderita $(1,92 \%)$ yang mengalami tipe reaksi reversal. Sisanya yaitu 6 penderita $(11,54 \%)$ tidak mengalami reaksi $\mathrm{MH}$.

Tabel 7 memperlihatkan berbagai penyakit penyerta yang dialami oleh penderita MH. Selain keadaan dari pada penyakit $\mathrm{MH}$ dan reaksi $\mathrm{MH}$ yang dialami oleh penderita, terdapat pula penyakit penyerta lainnya yang membuat penderita $\mathrm{MH}$ dirawat inap di rumah sakit. Didapatkan 3 penyakit penyerta terbanyak yang dialami oleh penderita MH yaitu gangguan gastrointestinal, gangguan elektrolit, dan anemia.

Tabel 2. Distribusi berdasarkan usia penderita $\mathrm{MH}$

\begin{tabular}{cccccc}
\hline $\begin{array}{c}\text { Usia } \\
\text { (tahun) }\end{array}$ & $\mathbf{2 0 1 6}$ & $\begin{array}{c}\text { Tahun } \\
\mathbf{2 0 1 7}\end{array}$ & $\mathbf{2 0 1 8}$ & Jumlah & \% \\
\hline 0 & 0 & 0 & 0 & 0 & 0 \\
$1-4$ & 0 & 0 & 0 & 0 & 0 \\
$5-14$ & 0 & 1 & 0 & 1 & 1,92 \\
$15-24$ & 2 & 3 & 6 & 11 & 21,15 \\
$25-34$ & 5 & 9 & 6 & 20 & 38,46 \\
$35-44$ & 3 & 4 & 2 & 9 & 17,31 \\
$45-54$ & 1 & 1 & 1 & 3 & 5,77 \\
$55-64$ & 1 & 1 & 3 & 5 & 9,62 \\
$65-74$ & 2 & 1 & 0 & 3 & 5,77 \\
$75+$ & 0 & 0 & 0 & 0 & 0 \\
Jumlah & 14 & 20 & 18 & 52 & 100 \\
\hline
\end{tabular}

Tabel 3. Distribusi berdasarkan jenis kelamin penderita $\mathrm{MH}$

\begin{tabular}{cccccc}
\hline Jenis kelamin & \multicolumn{3}{c}{ Tahun } & \multicolumn{3}{c}{ Jumlah } & \% \\
& $\mathbf{2 0 1 6}$ & $\mathbf{2 0 1 7}$ & $\mathbf{2 0 1 8}$ & & \\
\hline Laki-laki & 12 & 17 & 14 & 43 & 82,69 \\
Perempuan & 2 & 3 & 4 & 9 & 17,31 \\
Jumlah & 14 & 20 & 18 & 52 & 100 \\
\hline
\end{tabular}


Tabel 4. Distribusi berdasarkan tempat tinggal penderita $\mathrm{MH}$

\begin{tabular}{lccccc}
\hline \multicolumn{1}{c}{ Tempat tinggal } & Tahun & & Jumlah & $(\boldsymbol{\%})$ \\
& $\mathbf{2 0 1 6}$ & $\mathbf{2 0 1 7}$ & $\mathbf{2 0 1 8}$ & & \\
\hline Kota Manado & 4 & 8 & 7 & 19 & 36,54 \\
Kota Bitung & 1 & 0 & 0 & 1 & 1,92 \\
Kota Tomohon & 0 & 0 & 2 & 2 & 3,85 \\
Kab. Minahasa & 7 & 6 & 4 & 17 & 32,69 \\
Kab. Minahasa Utara & 1 & 2 & 2 & 5 & 9,62 \\
Kab. Minahasa Tenggara & 0 & 1 & 0 & 1 & 1,92 \\
Kab. Minahasa Selatan & 0 & 0 & 1 & 1 & 1,92 \\
Kab. Bolaang Mongondow & 0 & 1 & 2 & 3 & 5,77 \\
Kab. Bolaang Mongondow Timur & 0 & 1 & 0 & 1 & 1,92 \\
Kab. Sitaro & 1 & 0 & 0 & 1 & 1,92 \\
Di luar Sulawesi Utara & 0 & 1 & 0 & 1 & 1,92 \\
Jumlah & 14 & 20 & 18 & 52 & 100 \\
\hline
\end{tabular}

Tabel 5. Distribusi berdasarkan tipe MH

\begin{tabular}{cccccc}
\hline Tipe MH & & Tahun & & Jumlah & \% \\
& $\mathbf{2 0 1 6}$ & $\mathbf{2 0 1 7}$ & $\mathbf{2 0 1 8}$ & & \\
\hline Multibasiler & 14 & 20 & 18 & 52 & 100 \\
Pausibasiler & 0 & 0 & 0 & 0 & 0 \\
Jumlah & 14 & 20 & 18 & 52 & 100 \\
\hline
\end{tabular}

Tabel 6. Distribusi berdasarkan tipe reaksi MH

\begin{tabular}{|c|c|c|c|c|c|}
\hline \multirow[t]{2}{*}{ Tipe MH } & \multicolumn{3}{|c|}{ Tahun } & \multirow{2}{*}{ Jumlah } & \multirow{2}{*}{$(\%)$} \\
\hline & 2016 & 2017 & 2018 & & \\
\hline Reversal & 1 & 0 & 0 & 1 & 1,92 \\
\hline ENL & 10 & 20 & 15 & 45 & 86,54 \\
\hline Tidak ada reaksi & 3 & 0 & 3 & 6 & 11,54 \\
\hline Jumlah & 14 & 20 & 18 & 52 & 100 \\
\hline
\end{tabular}

Tabel 7. Penyakit penyerta yang dialami penderita $\mathrm{MH}$

\begin{tabular}{lcccc}
\hline \multicolumn{1}{c}{ Penyakit penyerta } & $\begin{array}{c}\text { Tahun } \\
\text { 2016 }\end{array}$ & $\mathbf{2 0 1 7}$ & $\mathbf{2 0 1 8}$ & Jumlah \\
\hline Gangguan gastrointestinal & 1 & 0 & 0 & 1 \\
Gangguan elektrolit & 10 & 20 & 15 & 45 \\
Anemia & 3 & 0 & 3 & 6 \\
Jumlah & 14 & 20 & 18 & 52 \\
\hline
\end{tabular}

\section{BAHASAN}

Berdasarkan hasil penelitian secara retrospektif yang telah dilakukan di Irina $F$ Kulit dan Kelamin RSUP Prof. Dr. R. D. Kandou Manado didapatkan bahwa sejak 1 Januari 2016-31 Desember 2018 terdapat 52 penderita dengan diagnosis $\mathrm{MH}$ yang dirawat inap di Irina F Kulit dan Kelamin dari total 149 penderita yang dirawat inap di Irina F Kulit dan Kelamin RSUP Prof. Dr. R. D. Kandou Manado (Tabel 1). Di Provinsi Sulawesi Utara, menurut data dari Kementerian Kesehatan Republik Indonesia angka prevalensi dari kasus MH dari 
tahun 2016-2018 mengalami peningkatan. ${ }^{5-}$

${ }^{7}$ Kurangnya tingkat kesadaran akan kesehatan khususnya untuk penyakit MH serta kurangnya upaya untuk memberantas penyakit ini baik dari pihak masyarakat maupun dari pemerintah merupakan salah satu faktor yang dapat menyebabkan terjadinya peningkatan angka prevalensi kasus $\mathrm{MH}^{8}{ }^{8}$ Terjadinya reaksi $\mathrm{MH}$ dan penyakit penyerta lainnya merupakan indikasi yang membuat penderita $\mathrm{MH}$ menjalani perawatan rawat inap di rumah sakit.

Ditinjau dari usia, didaspatkan bahwa penderita $\mathrm{MH}$ yang dirawat inap di Irina $\mathrm{F}$ Kulit dan Kelamin RSUP Prof. Dr. R. D. Kandou Manado pada tahun 2016-2018, penderita terbanyak berada pada kelompok usia 25-34 tahun yaitu sebanyak 20 penderita $(38,46 \%)$, paling sedikit terdapat pada kelompok usia 5-15 tahun dengan jumlah 1 penderita $(1,92 \%)$ dan tidak ditemukan penderita $\mathrm{MH}$ pada kelompok usia 0-4 tahun (Tabel 2). Penelitian sebelumnya yang dilakukan oleh $\operatorname{Seran}^{9}$ di RSUP Prof. Dr. R. D. Kandou Manado pada tahun 2009-2010 juga menunjukkan bahwa penderita $\mathrm{MH}$ terbanyak berada pada kelompok usia antara 25-44 tahun yang mencapai $51,85 \%$. Hasil penelitian ini sesuai dengan kepustakaan yang menyatakan bahwa frekuensi tertinggi berdasarkan usia dari penderita $\mathrm{MH}$ terdapat pada kelompok usia antara 25-35 tahun. ${ }^{1}$ Banyaknya kasus yang didapatkan pada kelompok usia tersebut diduga karena kelompok usia tersebut merupakan usia produktif yang memiliki aktivitas yang lebih banyak sehingga risiko untuk terpapar dengan penyakit MH juga lebih tinggi.

Ditinjau dari jenis kelamin, pada penelitian ini didapatkan penderita laki-laki lebih banyak dibandingkan perempuan, yaitu jumlah penderita laki-laki sebanyak 43 penderita $(82,69 \%)$ dan perempuan sebanyak 9 penderita $(17,31 \%)$ (Tabel 3). Perbandingan antara laki-laki dan perempuan ialah sebesar 4,8:1. Menurut data Kementerian Kesehatan Republik Indonesia pada tahun 2018, dari total kasus baru MH sebanyak 14.397 kasus, penderita lakilaki sebanyak $9.016(62,62 \%)$ dan perem- puan sebanyak $5.381(37,38 \%)$. Di Sulawesi Utara dari 443 kasus baru $\mathrm{MH}$ terdapat sebanyak 252 penderita laki-laki $(56,88 \%)$ dan 191 penderita perempuan $(43,12 \%))^{5}$ Penelitian yang dilakukan oleh Nuari $^{10}$ di Rumah Sakit Umum Pusat Sanglah menunjukkan hasil bahwa penderita laki-laki sebanyak $68,2 \%$ dan perempuan $31,8 \%$. Penelitian oleh Muhammad ${ }^{11}$ di Kabupaten Sampang, Provinsi Jawa Timur juga menunjukkan bahwa penyakit MH banyak diderita oleh laki-laki yaitu sebanyak $59 \%$ dan perempuan $41 \%$. Penyakit $\mathrm{MH}$ dapat menyerang semua orang baik laki-laki maupun perempuan, namun menurut beberapa laporan laki-laki lebih banyak terserang dibandingkan perempuan dengan perbandingan $2: 1{ }^{12} \mathrm{Hal}$ ini kemungkinan besar terjadi akibat lakilaki lebih banyak melakukan aktivitas di luar rumah sehingga risiko untuk terpapar dengan penyakit $\mathrm{MH}$ juga lebih besar dibandingkan dengan perempuan. ${ }^{13}$

Berdasarkan tempat tinggal, penderita MH paling banyak bertempat tinggal di Kota Manado yaitu sebanyak 19 penderita $(36,54 \%)$ (Tabel 4). Penelitian sebelumnya oleh Rompas ${ }^{14}$ di Poliklinik Kulit dan Kelamin BLU RSUP Prof. Dr. R. D. Kandou Manado pada tahun 2009-2011 juga menujukkan bahwa Kota Manado merupakan kota yang paling banyak ditemukan penderita $\mathrm{MH}$. Hal ini diduga disebabkan oleh karena kepadatan penduduk di Kota Manado yang tinggi hingga menyebabkan semakin mudah terjadinya penularan penyakit. Salah satu faktor yang juga diduga berpengaruh ialah karena RSUP Prof. Dr. R. D. Kandou terletak di Kota Manado maka penderita yang tinggal di Kota Manado lebih memilih untuk datang ke RSUP Prof. Dr. R. D. Kandou karena akses layanan kesehatan yang lebih dekat dan mudah untuk dijangkau.

Ditinjau dari tipe $\mathrm{MH}$, dalam penelitian ini didapatkan bahwa semua pasien $\mathrm{MH}$ yang dirawat inap di Irina $\mathrm{F}$ Kulit dan Kelamin RSUP Prof. Dr. R. D. Kandou Manado memiliki MH tipe MB yaitu sebanyak 52 penderita (100\%) (Tabel 5). Data dari Kementerian Kesehatan Republik 
Indonesia pada tahun 2018, menunjukkan bahwa MH tipe MB memiliki proporsi terbesar dari total keseluruhan 14.397 kasus, dimana $\mathrm{MH}$ tipe $\mathrm{MB}$ sebanyak 12.377 kasus $(85,97 \%)$ dan sisanya ialah MH tipe PB dengan jumlah 2.020 kasus $(14,03 \%)$. Di Sulawesi Utara pada tahun 2018 terdapat sebanyak 443 kasus baru MH, dimana 395 kasus $(89,16 \%)$ ialah $\mathrm{MH}$ tipe $\mathrm{MB}$ dan 48 kasus $(10,84 \%)$ ialah $\mathrm{MH}$ tipe PB..$^{5}$ Penelitian serupa yang dilakukan oleh Seran di RSUP Prof. Dr. R. D. Kandou Manado pada tahun 2009-2010 juga menunjukkan bahwa semua penderita MH yang dirawat inap di Irina F RSUP Prof. Dr. R. D. Kandou Manado memiliki MH tipe MB yaitu sebanyak 27 penderita $(100 \%) .{ }^{9}$ Banyaknya MH tipe MB yang ditemukan di rawat inap rumah sakit diduga disebabkan akibat terdapatnya tanda klinis yang jelas dari $\mathrm{MH}$ tipe $\mathrm{MB}$ yaitu berupa lesi kulit yang timbul di seluruh permukaan tubuh dan kondisi kesehatan yang menurun hingga menimbulkan kekhawatiran dalam diri penderita hingga menyebabkan penderita $\mathrm{MH}$ dengan tipe MB terdorong untuk mencari pengobatan di rumah sakit.

Ditinjau dari reaksi $\mathrm{MH}$, pada penelitian ini ditemukan bahwa reaksi $\mathrm{MH}$ yang paling banyak dialami oleh penderita $\mathrm{MH}$ yang dirawat inap di Irina $F$ Kulit dan Kelamin RSUP Prof. Dr. R. D. Kandou Manado ialah tipe reaksi eritema nodosum leprosum (ENL). Tipe reaksi ENL ialah sebanyak 45 penderita $(86,54 \%)$, tipe reaksi reversal sebanyak 1 penderita $(1,92 \%)$, dan sisanya yaitu 6 penderita $(11,54 \%)$ tidak mengalami reaksi $\mathrm{MH}$ (Tabel 6). Hal ini sesuai dengan penelitian yang dilakukan sebelumnya oleh Seran ${ }^{9}$ di RSUP Prof. Dr. R. D. Kandou Manado pada tahun 20092010 yang menunjukkan bahwa reaksi yang banyak dialami oleh penderita $\mathrm{MH}$ ialah reaksi ENL sebesar 92,59\%. Reaksi ENL merupakan indikasi yang paling banyak membuat penderita $\mathrm{MH}$ dirawat inap di rumah sakit. Penderita yang tidak mengalami reaksi $\mathrm{MH}$, mereka masuk dan dirawat di rumah sakit dengan keluhan penyakit penyerta lainnya seperti gangguan gastro- intestinal berupa mual dan muntah serta gangguan elektrolit dan anemia (Tabel 7).

Ditinjau dari penyakit penyerta yang dialami penderita $\mathrm{MH}$, baik penyakit tersebut disebabkan oleh $\mathrm{MH}$ maupun yang bukan akibat penyakit $\mathrm{MH}$ antara lain gangguan gastrointestinal (30 penderita), gangguan elektrolit (21 penderita), dan anemia (17 penderita) (Tabel 7). Penelitian oleh Pratiwi dan Agusni ${ }^{15}$ di RSUD Dr. Soetomo Surabaya menunjukkan bahwa sebagian besar pasien MH dengan reaksi ENL mengalami kelainan sistemik dan laboratoris seperti anemia sebanyak 70 penderita dan keluhan mual muntah sebanyak 50 penderita.

\section{SIMPULAN}

Penderita $\mathrm{MH}$ yang dirawat inap di Irina F Kulit dan Kelamin RSUP Prof. Dr. R. D. Kandou Manado pada periode 20162018 cenderung mengalami peningkatan jumlah, dan yang terbanyak didapatkan ialah kelompok usia 25-34 tahun, jenis kelamin laki-laki, asal Kota Manado, $\mathrm{MH}$ tipe MB (semua penderita), tipe reaksi ENL, dan penyakit penyerta ialah gangguan gastrointestinal.

Pada penelitian selanjutnya diharapkan untuk dilaksanakan penelitian lebih lanjut mengenai kasus $\mathrm{MH}$ dengan menggunakan variabel yang lebih banyak dan mencakup wilayah yang lebih luas.

\section{Konflik Kepentingan}

Penulis menyatakan tidak terdapat konflik kepentingan dalam studi ini.

\section{DAFTAR PUSTAKA}

1. Wisnu IM, Sjamsoe-Daili ES, Menaldi SL. Kusta. In: Menaldi SL, Bramono K, Indriatmi W, editors. Ilmu Penyakit Kulit dan Kelamin (7th ed). Jakarta: Fakultas Kedokteran Universitas Indonesia, 2017; p. 87-102.

2. Grayson W, Calonje E. Infectious diseases of the skin [Internet]. ClinicalKey. Elsevier Inc.; 2019 [cited 2019Aug 20]. Available from: https://www. clinicalkey.com/\#!/content/book/3-s2.0 B9780702069833000189?\%20scrollTo $=\#$ h10007576 
3. Leprosy [Internet]. World Health Organization. World Health Organization; 2019 [cited 2019 Nov30]. Available from: https: //www.who.int/news-room/factsheets/detail/leprosy

4. Leprosy. Number of new leprosy cases: 2018 [Internet]. World Health Organization. World Health Organization; 2019 [cited 2019 Nov 30]. Available from: http: //apps.who.int/neglected_diseases/ntdda ta/leprosy/leprosy.html

5. Data dan Informasi Profil Kesehatan Indonesia 2018. Jakarta: Kementerian Kesehatan Republik Indonesia.

6. Pusat Data dan Informasi Kementerian Kesehatan RI 2018. Hapuskan stigma dan diskriminasi terhadap kusta. Jakarta: Kementerian Kesehatan Republik Indonesia., 2018; p. 1-12.

7. Data dan Informasi Profil Kesehatan Indonesia 2016. Jakarta: Kementerian Kesehatan Republik Indonesia.

8. Tiwow PI, Kandou RT, Pandaleke HEJ. Profil penderita Morbus Hansen (MH) di Poliklinik Kulit dan Kelamin BLU RSUP Prof. Dr. R. D. Kandou Manado Periode Januari-Desember 2012. e-CliniC. 2014;2:1.

9. Seran EL. Profil penderita Morbus Hansen rawat inap di RSUP Prof. Dr. R. D. Kandou [Skripsi]. Manado: Universitas Sam Ratulangi; 2013.

10. Nuari H, Darmada IGK. Prevalensi dan karakteristik pasien morbus hansen tipe multibasiler yang mendapat terapi clofazimine, ofloxacin, dan minocycline (COM) di Rumah Sakit Umum Pusat Sanglah Periode Januari-Desember 2014. e-Jurnal Medika Udayana. 2015; $4(10)$.

11. Muhammad K, Santi M. Kurangnya konseling dan penemuan kasus secara pasif mempengaruhi kejadian kecacatan kusta tingkat II di Kabupaten Sampang. Jurnal Berkala Epidemiologi. 2015; 3(3):290-303.

12. Amiruddin MD. Penyakit kusta: sebuah pendekatan klinis. Firstbox Media; 2019 Jan 23.

13. Saragih RA. Gambaran epidemiologi penyakit kusta di Kecamatan Sui Kakap Kabupaten Kubu Raya Provinsi Kalimantan Barat Tahun 2012. Jurnal Mahasiswa PSPD FK Universitas Tanjungpura. 2014;1(1).

14. Rompas C. Profil pasien Morbus Hansen di Poliklinik Kulit dan Kelamin BLU RSUP Prof. Dr. R. D. Kandou [Skripsi]. Manado: Universitas Sam Ratulangi; 2013.

15. Pratiwi FD, Agusni I. Kelainan sistemik dan laboratorik pada pasien kusta dengan reaksi tipe 2/ENL di Divisi Kusta Unit Rawat Jalan dan Instalasi Rawat Inap SMF Kesehatan Kulit dan Kelamin RSUD Dr. Soetomo Surabaya periode 2011-2013. Berkala Ilmu Kesehatan Kulit dan Kelamin. 2018;30(1):18-25. 